\title{
From One Referendum to the Other: the Scottish Dimension to the Debate over Europe
}

D'un référendum à l'autre: la dimension écossaise du débat sur l'Europe

\section{Pauline Schnapper}

\section{CpenEdition}

Journals

Electronic version

URL: http://journals.openedition.org/rfcb/447

DOI: $10.4000 /$ rfcb.447

ISSN: 2429-4373

Publisher

CRECIB - Centre de recherche et d'études en civilisation britannique

Electronic reference

Pauline Schnapper, «From One Referendum to the Other: the Scottish Dimension to the Debate over Europe », Revue Française de Civilisation Britannique [Online], XX-2 | 2015, Online since 23 July 2015 , connection on 30 April 2019. URL : http://journals.openedition.org/rfcb/447 ; DOI : 10.4000/rfcb.447

This text was automatically generated on 30 April 2019.

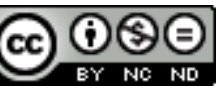

Revue française de civilisation britannique est mis à disposition selon les termes de la licence Creative Commons Attribution - Pas d'Utilisation Commerciale - Pas de Modification 4.0 International. 


\title{
From One Referendum to the Other: the Scottish Dimension to the Debate over Europe
}

D'un référendum à l'autre: la dimension écossaise du débat sur l'Europe

\author{
Pauline Schnapper
}

1 The Scottish referendum on 18 September 2014 was not only about the future of Scotland as an independent country and the future of the United Kingdom as a union state, important though that obviously was. It was also about the position of both Scotland and Britain in the European Union and about the more general role of sub-state entities in the $\mathrm{EU}$, as the presence of many Catalans, Corsicans, Basques and others in the streets of Edinburgh on referendum day illustrated. The European dimension to the Scottish referendum was obvious in the debates preceding the ballot, with the conditions for Scottish membership of the EU one of the main issues - together with the economy and defence - debated during the campaign, both directly and through the question of the currency of a possible independent Scotland. Europe was one issue which Yes supporters used to express the growing discrepancy between the Scottish and English political scenes.

2 The Scottish referendum can also be related to another, still putative referendum. The negative result of the vote on 18 September is likely to have an impact on the debate about a possible British exit from the $\mathrm{EU}$ if a referendum is organised in 2017, as promised by David Cameron in his Bloomberg speech on 23 January 2013, since Scottish public opinion is deemed more pro-European, or less eurosceptic, than the English one. With Scotland still part of the UK for the foreseeable future, a negative referendum on EU membership based on a majority of negative English votes could stir a political crisis in Scotland and renew calls for independence.

3 There is therefore a complex dynamic between the Scottish and the European referendums which did not stop in September 2014. This is what this paper aims to explore along four main dimensions. First the role of the EU in the Scottish referendum 
campaign will be assessed. It will appear that the SNP used Europe strategically in order to strengthen its case for independence, building on a supposed difference in European outlook between Scotland and England, the reality of which I will assess in section two by looking at opinion polls north and south of the border. Then I will show that this strategy collided with the extreme wariness of EU officials and European heads of government towards the idea of Scottish independence, for fear of encouraging further secession in Europe. Finally I will attempt to gauge the possible consequences of the Scottish No vote on the future of Britain in Europe.

\section{Europe as an asset in the yes campaign}

Europe played a significantly different part in the Scottish referendum campaign from what it usually does in British general elections, illustrating the growing difference between the London and Edinburgh political scenes. Unlike in the UK as a whole, the British eurosceptic parties are electorally very weak in Scotland, even if UKIP managed to win one seat there for the first time in the May 2014 European election. The Conservative party is only the third party in Scotland. The other parties on the Scottish political scene, the SNP, Labour and the Liberal Democrats, are all officially pro-European. Scottish membership of the EU was therefore not discussed per se in the referendum campaign, as the economic and social benefits of membership are not controversial in Scotland. Instead it was used as a tool by the Yes campaign.

5 This is not a new phenomenon. The SNP has pushed for "Independence in Europe" since 1988, acknowledging that sovereignty was relative in an interdependent world. Party leaders reached the conclusion that Europe would guarantee real autonomy for Scotland in a way which being a region in the UK did not. ${ }^{1}$ Indeed the national government and its policies would be made irrelevant. Membership of a wide single market would reduce the need for protection from the central state, which under the coalition government has reduced spending on the welfare state and is accused of neglecting the economic interests of the periphery. Europe would also reduce the costs of secession and improve the prospect of economic viability, a crucial argument in the SNP campaign. ${ }^{2}$ Membership of the EU, and of NATO for that matter, also provide an alternative source of security to the one traditionally provided by the nation-state. ${ }^{3}$ As Michael Keating put it, "the European institutional structure furnishes a set of opportunities for nonstate actors to intervene, gain recognition, build systems of action, and secure protection". ${ }^{4}$ It also allows Scottish nationalism to describe itself as inclusive and internationalist, as opposed to the English Tory/UKIP increasingly anti-EU nationalism. In other words, as Ichijo put it:

Europe helps the Scots to assert their moral superiority over, above all, the English and other nations in the world. They see themselves as a people with high moral standards - they care for community more than money. Unlike in many eurosceptic views, here the $\mathrm{EU}$ is not seen as an obstruct [sic] for democracy but as a defender of decent societal values. ${ }^{5}$

6 The yes campaign used two main arguments. First, at the moment Scotland cannot fully enjoy the benefits of EU membership because it is represented by London in Brussels. Under the Scotland Act 1998, European policy is decided in London, where the Cabinet takes into account the specific interests of Scotland, Wales and Northern Ireland. In Brussels, the UK representation similarly defends Scottish interests within the overall British position defined in London. A 1998 Memorandum of Understanding and three 
Concordats have established the details of decision-making and made it possible for Scottish ministers to attend the European Councils on some occasions. But the SNP did not see this as sufficient to safeguard Scottish interests in the EU:

Although Scottish Ministers can ask to attend Council, they can only do so with the permission of the relevant Secretary of State, and if granted permission to speak, must speak to the agreed UK negotiating line. This should in theory be a line that they have contributed to and agreed. However in practice the UK does not always ask for the views of Scotland, Wales or Northern Ireland, still less give those views due weight. Indeed, experience shows that a lead UK Department will rarely pursue a Scottish policy interest if it conflicts with their own dominant objective even if, as with the fishing industry, Scotland has the majority interest. ${ }^{6}$

Instead, with independence:

Scottish Ministers would be able to attend all Council meetings, and would be able to directly engage in key areas of decision making which only UK Ministers currently participate in, such as the future financing of the EU. We could prioritise issues for ourselves as a nation, and build alliances with other countries to negotiate to get the result which best serves our national interest. ${ }^{7}$

More money would flow from the common agricultural policy (CAP), Nicola Sturgeon even argued in a speech in January $2014 .{ }^{8}$ This was conveniently ignoring that, actually, research has shown that UK European decision-making smoothly adapted to devolution after 1997 and even after 2007, when the SNP was in power. The British representation in Brussels, in particular, has always been careful to include Scottish representatives and specific Scottish interests, such as in fisheries or structural funds, into its remit. ${ }^{9}$ The SNP's priority was to stress differences rather than acknowledge this rather successful process.

The second argument had to do with the current debate about a possible 'Brexit' in London and the weight of eurosceptic views in England, especially in the Conservative party and UKIP. Under these new circumstances, the Scottish Government had a fair point in arguing that "only independence will secure Scotland's long term membership of the EU". ${ }^{10}$ It put it clearly in 2013:

It seems clear that the UK has embarked on a path that will, at the very least, result in the UK Government having an increasingly marginalised role in key negotiations held in Brussels that will determine the future course of European integration. The Scottish Government wants Scotland to be at the heart of the EU decision-making process. That will only be possible if Scotland is able to take its place as an independent member of the EU. ${ }^{11}$

9 The argument resonated even more as more backbench Conservative eurosceptics in London put pressure on Cameron about an in/out referendum and contemplated leaving the EU. ${ }^{12}$

If Scottish voters wanted to stay in the EU, their best chance was therefore to vote Yes in the referendum. The SNP insisted that 18 months would be enough to secure transition to a new membership of the EU if voters chose independence, on the basis of article 48 of Treaty on the European Union which provides for amendments to the existing treaty through ordinary revision procedure, without the need to negotiate a new treaty. ${ }^{13}$ In their view Scotland would be able to keep the UK's opt-outs on the euro, the Schengen agreement, Justice and Home Affairs (which is actually an opt-in) and a share of the British rebate on the EU budget. On the currency, which proved a central point in the debate, the SNP recalled Scotland would not meet the convergence criteria to adopt the euro and therefore should be able to keep the pound. 


\section{Scottish opinion on Europe}

This strategy was based on the idea that on Europe the SNP was in tune with Scottish public opinion and that there was less hostility to the EU in Scotland than in England. This was not true in the 1975 referendum, when Scottish voters voted in favour of staying in the EC by a majority of $58 \%$ against $65 \%$ for the UK as a whole. ${ }^{14}$ By the late 1980 s though, public opinion in Scotland had indeed become more positive about membership of the EC, especially among SNP voters, at least partly as a result of the EC regional policy which granted millions of pounds to Scotland annually. A poll conducted in 1993 showed support for membership higher by 4 points in Scotland than in England (49\% against 45\% ), a significant though not dramatic difference. As Ichijo put it in 2008:

[T] he difference between Scottish opinion and that of the British is not particularly strong. However this discrepancy has been repeatedly observed in polls and analyses. The pattern is that Scots are more reluctant to oppose EU membership than the British people as a whole..$^{15}$

This has become even truer since the issue of a referendum on EU membership has resurfaced in the political debate in 2011, as the two polls shown here illustrate, the first one on Scottish opinion and the second one on the UK as a whole:

\begin{tabular}{|l|l|l|l|l|l|l|l|}
\hline & $\begin{array}{l}\text { Jan } \\
1999\end{array}$ & $\begin{array}{l}\text { Jan } \\
2000\end{array}$ & $\begin{array}{l}\text { Jan } \\
2003\end{array}$ & $\begin{array}{l}\text { Jan } \\
2004\end{array}$ & $\begin{array}{l}\text { Jan } \\
2005\end{array}$ & $\begin{array}{l}\text { Jan } \\
2013\end{array}$ & $\begin{array}{l}\text { Jan } \\
2014\end{array}$ \\
\hline Leave the EU & $10 \%$ & $11 \%$ & $11 \%$ & $13 \%$ & $14 \%$ & $19 \%$ & $17 \%$ \\
\hline Stay and reduce EU powers & $36 \%$ & $37 \%$ & $29 \%$ & $31 \%$ & $36 \%$ & $40 \%$ & $41 \%$ \\
\hline Leave things as they are & $21 \%$ & $21 \%$ & $24 \%$ & $27 \%$ & $21 \%$ & $25 \%$ & $23 \%$ \\
\hline Stay and increase EU powers & $14 \%$ & $13 \%$ & $19 \%$ & $12 \%$ & $13 \%$ & $8 \%$ & $7 \%$ \\
\hline $\begin{array}{l}\text { Work for single Euro } \\
\text { government }\end{array}$ & $9 \%$ & $9 \%$ & $8 \%$ & $7 \%$ & $5 \%$ & $3 \%$ & $3 \%$ \\
\hline Don't know & $10 \%$ & $8 \%$ & $8 \%$ & $9 \%$ & $11 \%$ & $6 \%$ & $8 \%$ \\
\hline
\end{tabular}

Source: Scottish Social Attitudes, 1999-2014, http://whatscotlandthinks.org/questions/ what-should-be-britains-long-term-policy-on-the-european-union\#table. 


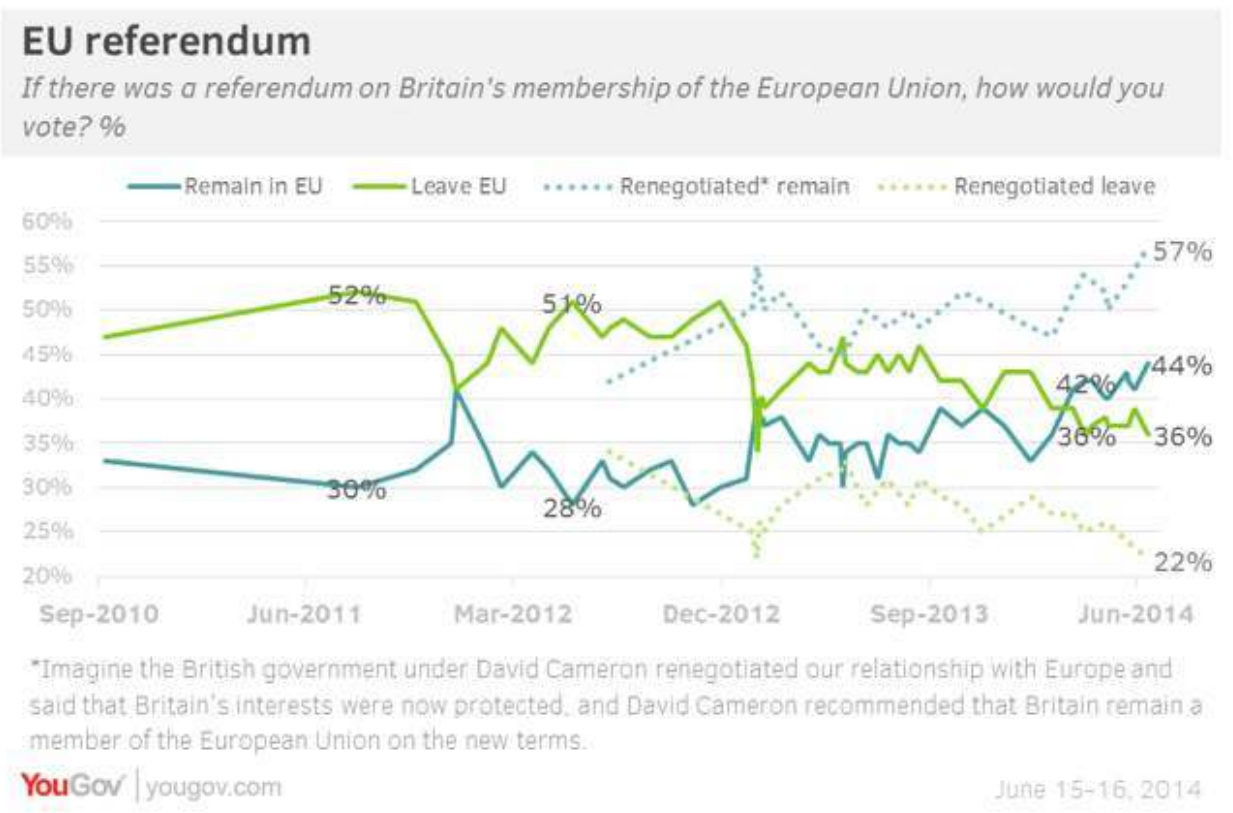

Source: YouGov, 15-16 June 2014, http://yougov.co.uk/news/2014/06/17/eu-referendum-record-lead/

\title{
The backlash against the yes campaign
}

\begin{abstract}
t) only appealed to $10 \%$ of the respondents in 2014 against $23 \%$ in 1999 (3) 3 .5\% in 2014 $35 \%$ in the UK as a whole) and opposition to the euro is also widespread, although less radical than in the UK. ${ }^{17}$ In 2001 already, Heasly had shown that euroscepticism did exist in Scotland (and Wales) and that much of Scottish pro-Europeanism was "instrumental" or utilitarian, as opposed to really europhile, i.e. based on the immediate benefits drawn, in particular, from structural funds rather than as a matter of principle. ${ }^{18}$ The difference between Scottish and English voters on Europe, though real, should nevertheless be qualified. But the graph also shows that the extent of europhilia in Scotland needs to be qualified,
since the federalist options (increasing the EU's powers and forming a single European
\end{abstract}

The SNP's strategic use of the EU to strengthen the case for independence met difficulties and opposition from a number of sources, which dented the impact it was able to make. As early as 2012, Alex Salmond had claimed that he had received legal advice confirming that an independent Scotland would be an automatic member of the EU and would inherit the UK's opt-outs. It appeared after a few months that there was no such official legal advice, exposing his stance as unrealistic. ${ }^{19}$

This weakness was used by the British Government which insisted that EU membership would not be automatic, whatever the SNP originally said:20 
[S]ince an independent Scottish state would be a new state, it would have to go through some form of accession process to become a member of the EU, which would involve negotiations on the precise terms of its membership. It cannot be assumed that Scotland would be able to negotiate the favourable terms of EU membership which the UK enjoys [...] Scotland's negotiations to join the EU could be complex and long, and the outcome could prove less advantageous than the status quo. ${ }^{21}$ Manuel Barroso, the president of the Commission and Herman von Rompuy, the president of the Council, insisted that an independent Scotland would have to go through a lengthy and possibly unsuccessful process to join the EU, not through article 48 but through the normal procedure of article 49 of the Lisbon Treaty. ${ }^{22}$ Barroso, in particular, said it would be "difficult, if not impossible" for Scotland to join the EU because of opposition from other member states with secessionist movements such as Spain, which for instance had still not recognised the independence of Kosovo, prompting an angry reaction from Alex Salmond..$^{23}$ Doubts were also voiced within the EU, and not just the British Government, as to whether Scotland would be able to keep Britain's opt-outs if it applied under article $49 .^{24}$

This barrage of criticism against the SNP undermined its strategy of independence in the EU and made it more difficult to sell it to the Scottish public. Whether it had an impact on the vote in the referendum ballot is nevertheless doubtful. Membership of the EU was apparently not a decisive factor in voters' choices. A poll conducted by Lord Ashcroft immediately after the referendum showed that EU membership was an important issue only for $12 \%$ of the Yes voters and $15 \%$ of the No voters, well behind domestic issues such as the NHS, pensions and defence. ${ }^{25}$

These criticisms also illustrated the impact of the referendum well beyond the British shores. Many EU member states felt extremely uncomfortable at the prospect of Scottish independence, not just because it would weaken one of the bigger states but because it would create a precedent for other separatist regions in countries like Spain or Belgium. Van Rompuy's insistence that "nobody has anything to gain from separatism in the world of today which, whether one likes it or not, is globalised" was telling in that respect. ${ }^{26}$ The "Europe of the Regions" celebrated at the time of the Maastricht treaty was no longer a reference for European institutions at a time when the EU was moving towards an increasingly intergovernmental framework as a result, in particular, of the financial and economic crisis. The voice of sub-state entities was no longer really celebrated in official discourse.

\section{Consequences on the EU referendum}

The Scottish referendum has also revealed other dynamics at play in the UK constitutional and European debate in the context of another promised referendum. In England, David Cameron was, as we have seen, under growing pressure from his backbenchers to promise a referendum on British membership. At first he resisted it, to the point of imposing a three-line whip against a motion demanding such a ballot in October 2011. But as he was also confronted with the spectacular rise of UKIP in opinion polls (which then translated into a victory in the May 2014 European elections and victories in two by-elections in the autumn that year), he promised in January 2013 to renegotiate the terms of British membership of the EU and to organise an in/out

Revue Française de Civilisation Britannique, XX-2 | 2015 
referendum in 2017 should the Conservatives still be in power after the 2015 general election. ${ }^{27}$

If the referendum takes place in 2016 or 2017 following a Conservative victory in the 2015 general election, the result of the Scottish independence vote will be significant. Scotland having voted to stay in the UK in 2014, Scottish voters would increase the probability of an overall positive result for staying in the EU. The impact would be limited since the Scottish population only represents $8 \%$ of the overall UK population, but it could be significant if the results are close.

On the other hand, if the UK as a whole, but not Scotland, chooses to leave the EU, the gap between the English and Scottish public opinion about Brexit could prove a major issue. This would most probably create a major political crisis in Scotland, where the SNP in particular could argue that the Scots are taken out of the EU against their will. This is why the new leader of the SNP, Sturgeon suggested Scotland should have a say:

Should a Bill be tabled in the House of Commons for a referendum on European Union membership, my party will table an amendment. That amendment will require that for the UK to leave the $\mathrm{EU}$, each of the four constituent nations England, Scotland, Wales and Northern Ireland - would have to vote to do so, not just the UK as a whole. This proposal transforms the terms of the UK debate on Europe - which so far has been all about the Westminster parties dancing to UKIP's tune. It would give proper protection against any of the nations of the UK being removed from the EU against their will. ${ }^{28}$

Unsurprisingly, Cameron immediately rejected the proposal and said there would be only one constituency in a referendum on the EU and that votes would not be counted regionally, in order to reduce the damaging political impact of widespread differences between the nations. Yet it is likely that the voting figures, or at least opinion polls, would become public and these differences would not stay concealed. In that case pressure for organising a new referendum on Scottish independence would increase again, a campaign which would be launched by the SNP but which would be equally embarrassing for Scottish Labour and Scottish Liberal Democrats, who would be caught between their support for a united kingdom and their wish for continued membership of the EU.

There are also lessons to be learnt from the Scottish referendum campaign for a possible future EU referendum campaign. First, the level of civic engagement and political participation in Scotland was impressive during the campaign and bodes well for an equally important referendum on the future of the UK in Europe. If the campaign manages to draw as much attention and participation in the debate and the vote itself, this could increase the chances of a positive result since we know that opinion about the benefits of EU membership is particularly volatile in the UK.

\section{Conclusion}

The Scottish independence referendum has sharply illustrated the difference in attitudes towards the European Union between England and Scotland. Whereas the English national debate is now about whether to remain in the EU or not, the campaign in Scotland was whether independence was the best way to ensure that Scotland would remain in Europe. The Yes campaign attempted (unsuccessfully, it turned out) to use the 
argument to press voters to support independence in spite of open hostility from several EU quarters to the prospect of Scottish independence.

The 18 September ballot was also revealing of more possible tensions in the future if a referendum on a British exit from the EU does take place in 2016 or 2017, as promised by the Conservative Party. With a majority of Scottish voters opposed to leaving the EU, a negative vote in the UK would trigger another constitutional crisis between England and Scotland. Unionist parties would most likely have to accept another Scottish referendum on independence, with the momentum for secession much stronger than in 2014. The fate of Scotland and of Britain in the EU will be closely intertwined.

\section{BIBLIOGRAPHY}

CLEMENTS, B. “Understanding 'Utilitarian' Support for European Integration in Scotland and Wales: the Role of Economic Interests, Identity and Party Support", Regional and Federal Studies, Vol. 21, No. 1, 2011, pp. 1-21.

FOREIGN OFFICE (2014). Scotland Analysis: EU and International Issues. January, available at:

https://www.gov.uk/government/uploads/system/uploads/attachment_data/

file/271794/2901475_HMG_Scotland_EUandInternational_acc2.pdf, accessed 2 November 2014.

HANRETTY, C., LAUDERDALE, B. \& VIVYAN, N. Comparing Strategies for Estimating Constituency Opinion from National Survey Samples. Working paper, Durham University, 2014.

HEASLY, R. "Euroskeptics, Europhiles and Instrumental Europeans: European Attachment in Scotland and Wales", European Union Politics, Vol. 2, No. 1, 2001, pp. 81-102.

HOLITSCHER, M. \& SUTER, R. “The Paradox of Economic Globalisation and Political

Fragmentation: Secessionist Movements in Quebec and Scotland", Global Society, Vol. 13, No. 3 , 1999, pp. 257-286.

ICHIJO, A. Scottish Nationalism and the Idea of Europe: Concepts of Europe and the Nation. London: Routledge, 2004.

ICHIJO, A. "The Uses of History: Anglo-British and Scottish Views of Europe", Regional and Federal Studies, Vol. 13, No. 3, 2008, pp. 23-43.

JEFFERY, Ch. “Scotland's International and European Policy » in Ferran REQUEJO (ed.), Foreign Policy of Constituent Units at the Beginning of the 21st Century, Barcelona: Institut d'Estudis Autonomics, 2010, p. 102-120.

KEATING, M. "European Integration and the Nationalities Question", Politics and Society, Vol. 32, No. 3, 2004, pp. 367-388.

PAQUIN, S. "Globalization, European integration and the rise of neo-nationalism in Scotland", Nationalism and Ethnic Politics, Vol. 8, No. 1, 2007, pp. 55-80.

SCOTTISH GOVERNMENT. Europe and Foreign Affairs: Taking forward our National Conversation, 2009, available at: 
http://www.scotland.gov.uk/resource/doc/283886/0086022.pdf.

SCOTTISH GOVERNMENT. Scotland in the European Union, 2013, available at: http:// www.scotland.gov.uk/Resource/0043/00439166.pdf.

WRIGHT, A. Who Governs Scotland?. London: Routledge, 2005.

\section{NOTES}

1. Alex WRIGHT, Who Governs Scotland?, London, Routledge, 2005, p. 20.

2. Atsuko ICHIJO, Scottish Nationalism and the Idea of Europe: Concepts of Europe and the Nation, London: Routledge, 2004, pp. 91-93; Mark HOLITSCHER and Roy SUTER, "The Paradox of Economic Globalisation and Political Fragmentation: Secessionist Movements in Quebec and Scotland", Global Society, Vol. 13, No. 3, 1999, pp. 257-286

3. Stéphane PAQUIN, "Globalization, European Integration and the Rise of Neo-nationalism in Scotland", Nationalism and Ethnic Politics, Vol. 8, No. 1, 2007, pp. 55-80.

4. Michael KEATING, "European Integration and the Nationalities Question", Politics and Society, Vol. 32, No. 3, 2004, p. 383.

5. Atsuko ICHIJO, op. cit., 2004, p. 99.

6. SCOTTISH GOVERNMENT, Europe and Foreign Affairs : Taking Forward our National Conversation, $2009, \$ 2.4$, available at:

http://www.scotland.gov.uk/resource/doc/283886/0086022.pdf.

7. Idem, § 5.20.

8. "Scottish independence: EU financial benefit outlined", The Scotsman, 16 January 2014.

9. Charles JEFFERY, "Scotland's International and European Policy" in Ferran REQUEJO (ed.), Foreign Policy of Constituent Units at the Beginning of the 21st Century, Barcelona: Institut d'Estudis Autonomics, 2010, p. 102-120.

10. SCOTTISH GOVERNMENT. Scotland in the European Union, 2013, § 1.15, available at http:// www.scotland.gov.uk/Resource/0043/00439166.pdf.

11. Idem, § 2.29 .

12. "Scottish independence: EU stay 'needs' Yes vote", The Scotsman, 15 May 2013.

13. See the full article at http://www.lisbon-treaty.org/wcm/the-lisbon-treaty/treaty-oneuropean-union-and-comments/title-6-final-provisions/135-article-48.html.

14. Ben CLEMENTS, “Understanding 'Utilitarian' Support for European Integration in Scotland and Wales: the Role of Economic Interests, Identity and Party Support", Regional and Federal Studies, Vol. 21, No. 1, 2011, p. 8.

15. Atsuko ICHIJO, "The Uses of History: Anglo-British and Scottish Views of Europe", Regional and Federal Studies, Vol. 13, No. 3, 2008, p. 39.

16. Chris HANRETTY, Ben LAUDERDALE \& Nick VIVYAN, Comparing Strategies for Estimating Constituency Opinion from National Survey Samples. Working paper, Durham University, 2014.

17. Atsuko ICHIJO, op. cit., 2004, p. 141-2.

18. Richard HEASLY, "Euroskeptics, Europhiles and Instrumental Europeans: European Attachment in Scotland and Wales", European Union Politics, Vol. 2, No. 1, 2001, pp. 81-102.

19. "Alex Salmond Accused of Misleading Scottish Voters about EU Legal Advice", Guardian, 23 October 2012.

20. See SCOTTISH GOVERNMENT 2013, op. cit., p. 1.

21. FOREIGN OFFICE, Scotland Analysis: EU and International Issues, January 2014, p. 55, available at: https://www.gov.uk/government/uploads/system/uploads/attachment_data/

file/271794/2901475_HMG_Scotland_EUandInternational_acc2.pdf, accessed 2 November 2014. 
22. This states that "any European State which respects the values referred to in Article 2 and is committed to promoting them may apply to become a member of the Union. The European Parliament and national Parliaments shall be notified of this application. The applicant State shall address its application to the Council, which shall act unanimously after consulting the Commission and after receiving the assent of the European Parliament, which shall act by an absolute majority of its component members. The conditions of admission and the adjustments to the Treaties on which the Union is founded, which such admission entails, shall be the subject of an agreement between the Member States and the applicant State. This agreement shall be submitted for ratification by all the contracting States in accordance with their respective constitutional requirements" (Lisbon Treaty, article 49).

23. "Independent Scotland 'would Find it Extremely Difficult to Join EU”, Guardian, 16 February 2014.

24. “Scottish Independence: EU Opt-outs 'Difficult”, Scotsman, 16 June 2013.

25. "Scottish Independence: Poll Reveals Who Voted, How and Why", Guardian, 20 September 2014.

26. Quoted in "European Chief Pours Scorn on Scottish Independence", Observer, 4 November 2012.

27. David CAMERON, EU speech at Bloomberg, 23 January 2013, available at https://www.gov.uk/ government/speeches/eu-speech-at-bloomberg.

28. Quoted in "Nicola Sturgeon Calls for Scottish Veto on Referendum", Guardian, 29 October 2014.

\section{ABSTRACTS}

This paper examines the role played by the European issue in the Scottish referendum campaign, especially the way the SNP tried to use it to its advantage. It also focusses on the complex interplay between the Scottish referendum on independence and the possible future referendum on 'Brexit' which was promised by David Cameron for 2017, in particular looking at the different scenarios possible.

Cet article examine le rôle joué par la question de l'appartenance d'une éventuelle Écosse indépendante à l'Union européenne pendant la campagne référendaire et l'utilisation qui en a été faite par le camp indépendantiste. Il met en lumière la dialectique complexe entre le référendum écossais et l'organisation éventuelle d'un référendum sur le 'Brexit', promis par David Cameron pour 2017, en évoquant les différents scénarios envisageables.

\section{INDEX}

Keywords: European Union, referendum, Scotland, SNP, European Commission

Mots-clés: Union européenne, référendum, Écosse, SNP, Commission européenne 
AUTHOR

PAULINE SCHNAPPER

Université Sorbonne Nouvelle Paris 3 and Institut Universitaire de France 